\title{
Critique of the Democratic Potentialities of the Internet: A Review of Current Theory and Practice
}

\author{
Yana Breindl
}

Université Libre de Bruxelles, Department of Information and Communication Sciences, Belgium, ybreindl@ulb.ac.be

\begin{abstract}
Many scholars have hailed the democratic potential of the internet. For some it empowers individuals and fosters genuine political discussions. For others, it is perceived as a threat, a Machiavellian tool that inevitably leads to increased State surveillance and monitoring of its citizens. After the turn of the century, a growing body of literature reveals the gap between the supposed democratic potentialities of the internet and the practices emerging in the field. This paper reviews recent literature on online activism and e-mobilization and argues that each potential conceals a continuum rather than a binary division. In order to deconstruct the democratic potential of the internet, we base this reflection upon the three axes proposed by Vedel (2007) for making sense of the political uses of the internet: information, discussion and mobilization. For each of these dimensions, one can find evidence of an empowering aspect of the technology as well as of how it poses new challenges to citizens. To name just one example, increased access to information can lead to a better informed citizenry but may also lead to issues of information overload and practices of disinformation.
\end{abstract}

Keywords: Internet politics, activism, public sphere, social capital, democracy, mobilization, dichotomies.

Acknowledgement: The Université Libre de Bruxelles for founding my four-year PhD scholarship.

The emergence and fast adoption of the internet by a wide range of individuals, groups and protest movements has given rise to a vast literature discussing the advantages and disadvantages of the use of ICTs for promoting social change. One characteristic of the studies ranging from the 1990s to the early 2000 is their speculative nature. On the one hand, authors hail the empowering potential of the internet, prophesying the advent of a cyberdemocratic society where all citizens are equal (e.g. Lévy, 2002) or the emancipation of citizens from state power and market forces (e.g. Morris \& Delafon, 2002). On the other hand, authors fear the alienating effects of increased computer use and networks in society, which could only lead to depression and social isolation.

John Perry Barlow's 'Declaration of Independence of Cyberspace' (1996) is one of the most famous examples of cyber-enthusiasm sustained by techno-libertarianism. Proclaiming the ungovernability of cyberspace, Barlow narrates, and thus metaphorically generates cyberspace, the new "home of minds". Bar- low's performative document is soaked with exaggerated rhetoric and hyperboles, characteristic of the hype surrounding internet technologies. The declaration "promote[s] an 'impossible future' that is blind both to the history of its underlying technologies and to the politics on which it claims to base itself" argues Morrison (2009: 58). For Barlow, the underlying technology of 'cyberspace' empowers the individual as it shifts the power from governmental institutions to individual citizens. Fifteen years after its publication, the declaration is increasingly mocked as utopian musing.

Similarly, Lévy anticipated the fall of dictatorships around the world and the advent of what he refers to as cyberdemocracy. "The destiny of democracy and cyberspace are intimately linked because they both involve what is the most essential to humanity: the aspiration to freedom and the creative power of collective intelligence" argues the philosopher (2002: 33) using very little facts to sustain his argument.

For others, the internet would overcome the shortages of previous media - such as the 
radio or television - and strengthen democracy worldwide. In sum, "it has seemed as if, in one fell swoop, the cure has been identified for suffering democracies, to the point of attributing to ICTs the power to save them" resumes Bentivegna (2006: 336).

When linked to the "meta-narrative of democracy" (Bentivegna, 2006: 332), optimistic and pessimistic discourses reach new heights. This trend is reinforced by the fact that representative democratic systems have become ever more contested in many Western societies. Political scientists observe increased voter apathy and a general detachment of citizens from conventional politics in most Western democracies. Traditional political institutions such as governments or parliaments face a loss of legitimacy along with public dis-engagement ('desertion' following Hardt and Negri, 2000). The emergence of a medium offering the potential to (re)connect citizens to their decision-makers raises high expectations of an advent of more Athenianstyle democracies.

Such discourses have soon been opposed by a more pessimistic strand of literature stressing the internet's potential use for increased state surveillance at the expense of civil liberties such as privacy (e.g.: Van De Donk, 1995). For cyber-pessimists, ICTs alone do not suffice to change the democratic process due to the political system's reluctance to change and the unwillingness of citizens to transform themselves into 'good citizens' (Bentivegna, 2006). As a result, the internet would simply become an additional but not disruptive - channel in the political game (Hill \& Hughes, 1998; Margolis \& Resnick, 2000). More generally, the internet is accused of leading to an atomized society in which individuals experience loneliness and isolation. Dreyfus (2001) rejects the positive claims surrounding the internet as "hype". He argues that "the more we use the Net, the more it will tend to draw us into the unreal, virtual worlds populated by those who want to flee all the ills that flesh is heir to" (2001: 137).

The dystopian or Orwellian scenario interprets the growing use of ICTs in the political process as the advent of a generalized surveillance state, a Big Brother made possible by information networks at the expense of civil liberties. Such a state is characterized by simulacrum and manipulation, a growing gap between "information-rich" and "information poor", the fading away of general interest due to the fragmentation of the political demand and the impossibility to build a long term future in a time of permanently direct and realtime consultations (Massit-Folléa, 1997).

If nuances run through both the optimistic and the pessimistic strands of the literature, a recurrent criticism is that they are often based on a certain technological determinism. They are emblematic for the emergence of any new technology and not particular to the case of the internet (Vanobbergen, 2007). Similar narratives surrounded the emergence of previous technologies such as the telegraph, the radio or television. The hype surrounding the internet and its application to politics is yet another crystallization of the general hype surrounding the advent of any new technology. They need to be linked to discourses by technological utopians like Nicholas Negroponte, Bill Gates or more recently Manuel Castells who advocate the advent of an information or network society profoundly different from the society built since the industrial revolution in the early nineteenth century (Vanobbergen, 2007).

For Flichy (2001), utopian and dystopian exclamations are not only media deterministic but also a-historical. "These discourses conceal that mythmaking is inherent to technological development and that the introduction of 'new' media in the past (telegraph, telephone, radio, television) was also surrounded by 'doom' and 'boom' scenarios about their effects on society" argues Vanobbergen (2007: 2). Hopeful and fearful proclamations about 'new media' bear a recurrent pattern, as they repeat themselves throughout history (ibid.). Despite ongoing criticism, such a polarization keeps on repeating itself with the introduction of every new wave of ICTs, most recently social media or Web 2.0 applications like Facebook or Twitter.

\section{Towards a Conceptualization of In- ternet Activism}

Utopian and dystopian accounts of the potential of ICTs for empowering resource-poor 
actors are particularly alive concerning research on political activism. More empirically based studies have emerged after the dotcom bubble burst in the early 2000s and the appearance of ever more citizen initiatives involving ICTs for influencing policy making. Many case studies analyze how the internet shapes current political trends and in particular, in which way activists or, social movements (SMs) other citizen networks use it for making their voice heard.

One of the critiques voiced against the optimist and pessimist research literature of the early years is that they were based on a traditional conception of politics. Using conventional indicators to measure in which way the internet is being used by citizens scholars report no significant changes. Following some authors, transformations have nonetheless occurred, but in order to fully understand these, one needs to reconsider the study of politics. Following Bentivegna (2006), protest groups such as social movements, civic associations, issue groups or discussion groups are indicators of what Giddens (1991) and Beck (1997) have respectively theorized as 'life politics' or 'sub-politics'. This kind of politics takes place beyond the formal political arena, "at the margins of the system, in the domain of informal politics" (Dahlgren, 2004: xviii). Traditional political institutions such as the nation state are contested in an era of globalization, characterized by dense networks of communication. As a result politics are "materializing in different ambits and contexts, thus meaning the loss of 'centre' as a consequence of the crumbling of the traditional political institutions that previously had control of it" (Bentivegna, 2006: 332). At present, citizen engagement is less shaped by large structuring ideologies or the formal political process (Cammaerts and Van Audenhove, 2005). Issues closer to everyday life, identity-politics or single-issues such as child abuse or animal rights constitute important triggers for citizen involvement.

This shift in political practices has been accompanied by the emergence of the internet in the early 1990s. It is therefore not surprising that scholars have glorified its democratic potentialities among which its reach, speed, reduced costs, information richness, decentralization, absence of censorship, search en- gines and the rise of user-generated interactive platforms (Rucht, 2005). Research investigating the use of the internet for collective action constitutes an important part of this literature. The next paragraphs review research in this area before proposing three axes for analyzing the democratic potential of the internet.

\subsection{Beyond the Social Movements Para- digm}

Social movements (SMs) can be considered "as the institutionalization of particular struggles" (Cammaerts, 2007: 217). They are characterized by three elements: they aim for social change, adopt identity-based network structures and use 'unconventional' means of protest (Rucht, 1994). Social movements can be defined as networks of social actors who engage in sustained collective actions, have a common purpose and challenge established elites (Tarrow, 2006).

Van De Donk et al. in the preface to their anthology on new media and social movements consider that: "as a means of facilitating the creation of cross-national, 'disorganized' networks for collective action on the basis of negotiated common concerns, the internet might almost have been purpose-built for social movements" (2004: xvii). The internet is indeed attractive for social movements as it facilitates mesomobilization (i.e. the coordination between various movements across borders). It also allows reaching many with little resources, and offers the possibility to bypass state control while retaining editorial control over content and external communication (Scott and Street, 2000). All in all, it is perceived as a medium that empowers resource-poor actors who can constitute counter-publics in order to contest the mainstream public sphere.

It is not surprising therefore that most of the literature tends to adopt the 'social movements paradigm' (Tarrow, 2006) in order to make sense of the way the internet is used for political activism. Van De Donk et al. propose to make sense of "cyberprotest" by referring to the classical social movement concepts of resource mobilization, political opportunity structure and ideology, identity and persua- 
sion approaches (2004: 14). Similarly, Garrett (2006) adopts McAdam et al. (1996) framework, based on the concepts of mobilizing structures, opportunity structures and framing processes, in order to organize his review of the relationship between social movements and new ICTs. The framework of 'contentious politics' advanced by McAdam et al. (2001) integrates these various processes and mechanisms.

Science and technology studies (STS) have focused on social movements as "one of the main pathways toward increased democratic participation". STS has been interested in how reform movements or counter-movements have advocated change in scientific fields, how SMs have adopted and reconfigured technology in instrumental and expressive ways and how scientists have collaborated with SMs to oppose policies supported by elites and advocate alternatives (Hess et al., 2008). This has particularly been the case in what is considered as the "new social movements' (NSMs), i.e. health, environmental, the peace, and information/media reform movements (ibid.).

'Social movements' use of the internet is one of the few areas where the much vaunted but rarely realized 'democratic promise' of the internet is at least partially borne out," argue Hess et al. (2008: 476). Yet, the debates about the democratic potential of the internet occurring today have been preceded by debates on 'computerization movements'. Just as with the internet, the computer has been considered as a tool of empowerment for individuals or, on the contrary, a source of alienation for individuals and society at large (ibid.).

STS studies have been decisive in advancing the view of a co-production of technologies and social forms. The 'turn to technology' in the 1980s argues that technology is not merely determining human action but that, on the contrary, human action and social forces are shaping technology. This leads to a critic of social constructivist determinism, meaning that technology is solely shaped by social actions. More recently, STS supports the thesis that social and technological forces mutually co-produce each other.

For Powell, the "democratic imaginations of computer technology establish alternatives to the dominant institutional frameworks for computers - even while they contribute to them" (2008: 1). They are associated with "disruptive and oppositional political positions" while at the same time they support "the status quo of post-industrial, informational capitalism" (ibid.). The internet, and technology in general, constitute on the one side a resource for building the identity, organization and action of SMs, but on the other side, an integral part of the "enemy" against which to mobilize. "They are viewed as instruments of the dominant power and as responsible for the perverse effects of globalization, especially so now that the connection between scientific research and economic interests is increasingly apparent" write Bucchi and Neresini (2008: 454). The relation between technology and protest actors is thus far from being unequivocal. Technology is not only used by protest actors but can also constitute a target for collective action.

Empirically based research on the appropriation and use of ICTs by social movements provides useful insights into how protest actors are using these tools. However, internet activism and e-mobilization seem to encompass a broader field than sole social movements approaches. Chadwick defines emobilization as the "uses of the internet by interest groups and social movements for political recruitment, organization, and campaigning" (2006: 114). Both interest groups and social movements constitute agents of mobilization but are traditionally distinguished by political scientists. However, this distinction is increasingly questioned (e.g. Burstein, 1998) as 'organizational hybridity' and 'repertoire switching' characterize current protest movements (Chadwick, 2007).

"Established interest groups and parties are experiencing processes of hybridization based on the selective transplantation and adaptation of digital network repertoires previously considered typical of social movements", states Chadwick (2007: 283). At the same time, "new organizational forms are emerging that exist only in hybrid form and that could not function in the ways that they do without the internet and the complex spatial and temporal interactions it facilitates" (ibid). These "hybrid mobilization movements" - MoveOn is the most frequently cited example - use a mixture of repertoires that used to be associ- 
ated with the three traditional political actors: political parties, interest groups, and social movements. Even though this organizational adaptation should not be generalized, a pure social movements approach to studying internet activism can hardly be upheld.

Social movements are not the sole users of ICTs. In fact, there is a great variation in organizational structures that rely on ICTs to promote social and political change (Bimber et al., 2005). Internet-supported collective action adopts both formal and informal structures, i.e. hierarchical, bureaucratic structures and horizontal, networked structures. Furthermore, Bimber et al. argue that "with the rise of micromedia (email, chat rooms \& cell phones) and 'middle' media (websites, webzines, internet-based communication campaigns), formal organizations, flexible decentralized organizations, networks, and even individuals now have the potential to communicate and coordinate with others in ways that until recently were feasible almost exclusively for formal organizations" (Bimber et al., 2005: 375).

The majority of the extant literature has focused on how established institutions - political parties, interest groups and social movement organizations - use internet tools to organize protest actions. However, following Earl and Schussman (2003), ICTs reduce the incentive to join established organizations such as SMs. 'Movement entrepreneurs', i.e. non professional individuals motivated by personal interests and relying on their own skills for undertaking movement activity (Garrett, 2006) emerge as new agents of mobilization that are not necessarily linked to social movements.

Furthermore, the advent of social media or, as it is often referred to, of Web 2.0 applications, offers new possibilities for more individualistic protest activities based on usergenerated content. On such sites, individuals themselves generate and control creation processes such as posting, classifying or evaluating content online. Häyhtiö and Rinne consider that "most issue-specific individually orientated political interventions differ both from the traditional social movements, as well as from the 'new social movements' in respect to their agenda, aims, temporal duration, and lines of chosen activities" (2008: 26). The growing number of social media applications poses a new challenge to this field. This evolution is in line with a general process of individualization that is shaping political practices (Dahlgren, 2009). Citizens tend to make political connections by following personal interests and life-style choices rather than overarching traditional ideologies. The role of individuals, notably bloggers (e.g. Kahn and Kellner, 2004), in shaping current political discussions is therefore crucial to understand how the internet is used for protest activities while it hardly falls within the social movements paradigm.

What roles do internet related technologies play in this fast changing political landscape? Are some forms of protest, some actors empowered by the use of new communication technologies or do established political actors benefit most from technological innovations? Before examining these questions in more detail, we should also wonder in which way the internet has been conceptualized by the literature. Is there one uniform understanding of what the internet represents? What about the confusion surrounding the use of concepts like "new media" or "ICTs"?

\subsection{The Internet, New Media and ICTs}

For Kahn and Kellner, the internet is "a living, historical force and one of the keys to understanding and shaping the political and cultural life of present age" (2004: 88-89). The internet enables researchers to study in unprecedented ways protest movements and internet-based political campaigns. Yet for many, these technologies seem to be part so much of current information societies that there is no much need to clearly define them. For Salter, "the internet has become an unclear concept. Whereas it is recognized in dictionaries as a noun, it is also subject to normative description and use, which, to paraphrase Wittgenstein, determines its meaning" (2003: 118). Some scholars refer exclusively to new media; others to ICTs while some use the net, internet, the network of networks interchangeably.

From a technological perspective, the internet can be defined as a network of computer networks. However, the person or group who 
uses it for a certain purpose and in a certain way will highly determine the character of the internet. Therefore, scholars can not only assume a technical definition of the internet but also need to take into account what social construction the actors they are studying confer to it (Salter, 2003).

This endeavor is further complicated by the fast development of internet-based technologies. If early studies examining the political use of the internet based their research on applications such as bulletin board systems (BBS), e-mails and local area networks - e.g. Bill Dutton's (1996) study of the Santa Monica Public Electronic Network - current research is more concerned with social networking sites such as Facebook or MySpace (e.g. Neumayer \& Raffl, 2008, Valenzuela et al., 2009) or the latest technological innovations such as Twitter. For Salter (2003), there remains a methodological difficulty to compare early internet technologies with current web developments.

Furthermore, the number of internet users has increased exponentially as has the multitude of applications currently available. Speaking solely about "the internet" may therefore make little sense as the concept is large and ambivalent. What is generally meant when referring to the internet are the applications that evolve around it: e-mails, chat rooms, weblogs, BBS, and of course the World Wide Web that constitutes a privileged access point to the internet. With technological development, previous communication technologies such as for example the telephone, radio or television, are converging and growing increasingly interdependent. Therefore, many scholars prefer to speak about information and communication technologies (ICTs). As argued by Bimber et al.: "attempting to maintain a distinction between the internet and telephony, or between information technology and communication technology, is not always fruitful" (2005: 369).

Considering the internet as a technology rather than emphasizing its information and communication capabilities "signals a tendency for technological determinism" argues Polat (2005: 435). In her paper examining the links between the internet and political participation, she therefore distinguishes the internet as an information source, a communication medium or a virtual public sphere (these concepts will be discussed in section 2). Indeed the way in which scholars conceptualize the internet gives strong indications on which aspect of the internet their study focuses on. Van De Donk et al. (2004) for example use the term 'new media' when addressing the internet. They thus conceptualize it as a communication media, generally considered as an alternative source of information. For Yzer and Southwell (2008), using new media as a synonym for the internet is nonetheless problematic. From the initial network of interconnected computers, the internet has evolved to an immense array of applications supporting human interaction. "Each of these possibilities (e.g. blogs, chat rooms, e-mail, instant messages, mobile phone calls, and hyperlinks) likely presents unique conditions for human interaction" (2008: 9). Furthermore, mobile technologies offer extensions for information exchanges outside the internet. The common attribute these various technologies share is that, contrary to broadcast applications, they offer channels of one-to-one and many-to-many communication. In this paper, we use ICTs or the internet to refer to networked digital tools used for protest activities.

Since the early 2000, a whole range of new applications generally characterized as Web 2.0 or social media appeared, and are increasingly used by activists. These applications range from social networking sites such as Facebook or MySpace to collaborative sites such as Wikipedia or Flickr. They are based on the collaborative creation and sharing of content, easy-to-use forms of selfpublishing and social networking. They offer new possibilities such as the propagation of content over multiple applications, rich user experiences on political websites or the creation of small-scale forms of political engagement through consumerism (Chadwick, 2009). Thresholds for participation are lowered and Web 2.0 applications relaunch discussions about their propensity to reinforce networked protest. However, research on the use of Web 2.0 by citizens and protest groups is still scarce. Most of this literature focuses on established political actors (e.g. Lilleker and Jackson, 2008). Whatever technology is examined, the attitude individuals or groups adopt towards technology is a strong explana- 
tory factor for how and in what way these technologies will be used.

\subsection{Attitudes Towards Technology}

As Gillan formulates it: "the attitudes that people bring with them to the engagement with technology - what Kirkpatrick (2004) calls 'computational temperaments' - delimit the potential that may result from activists' adoption of ICTs" (2008: 75). Based on his observations of a UK anti-war group's adoption of technology and innovation, he distinguishes between two main attitudes: the user and the hacker attitude. The user-oriented approach to technology is characterized by the fact that activists mainly use new communication devices as tools in the spirit of what they were invented for.

The hacker attitude takes a more innovative approach, stretching and bending the functions of technological devices in order to find new ways to mobilize participants. Following Gillan, the second attitude is particularly beneficial when the "pursuit of collective action requires horizontal communication structures" (2008: 76). At least in the anti-war movement, the hacker attitude is rather the exception. Social movements adoption of technology is often more based on efficiency than on the potential benefits of experimentation.

Hackers or hacktivists, a contraction of hacker and activist, form a particular type of protest actors and are sometimes considered as the first proper social movement of information technology and current societies (Riemens, 2002). If other types of protest actors hesitate to integrate ICTs, considered as instruments of techno-capitalist domination, hackers are passionate about exploring the technical capacities of computers and networks and were highly involved in the early shaping of personal computing and the internet. The media may have built a cultural cliché that conflates hackers with criminals. Yet, hackers are primarily computer aficionados who share a common 'hacker ethic' of sharing, openness, decentralization, free access to computers and the wish to contribute to a certain world improvement (Levy, 1984). "It is a culture of technological creativity based on freedom, cooperation, reciprocity, and informality," asserts Castells (2001: 50).

Hackers need to be distinguished from other social movements and how these use ICTs. As Riemens (2002) points out, the range of political beliefs held by individual hackers, without loosing a common sense of belonging and identity, is simply unimaginable in other 'social movements'. Hackers are inspired by libertarianism but generally despise preconceived opinions and positions (Riemens, 2002). Their political aims are an infinite pursuit of free knowledge linked to a pragmatic and "engineering philosophy to 'make things work"' (Berry, 2008: 102).

Various generations of hackers have been identified by the literature (e.g. Levy, 1984; Jordan \& Taylor, 2004). The most straightforward political expressions are the Free/Libre and Open Source software movement and hacktivism, defined as the use of hacking principles for promoting social change. If hacktivists hold similarities with social movements - a collective identity for example - it remains open to discussion whether such forms of political actions can and should be considered as social movement activity.

As already discussed previously, many forms of internet activism are not constrained to social movements. Loose networks of activists or the multiplication of single-issue campaigns are on the contrary more focused and ephemeral than social movement activity. Yet, one of the most salient characteristics of internet-based protest groups is that communication becomes the foremost political strategy, making "campaigns, themselves, political organizations that sustain activist networks in the absence of leadership by central organizations" (Bennett 2004: 130). Upholding a pure 'social movements paradigm' does thus not suffice to account for the heterogeneous field of internet activism.

Undertakings to stabilize the concept of internet activism are challenging endeavors in regard of the variety of forms, objectives, strategies, attitudes, etc. encountered. As we have seen above, these vary significantly following the way scholars understand core concepts such as "the internet" and "collective action". The following section therefore seeks to highlight different approaches to these concepts in the literature. 


\subsection{Classifying Types of Internet Activ- ism}

Attempts to classify various forms of online activism have remained the exception. Most of the literature focuses on a single organization or event, such as the European Social Forum (Kavada, 2005, 2008), a particular issue movement such as the Zapatistas (e.g. Ronfeld and Arquilla, 2001; Garrido, Halavais, 2003), the anti-globalization movement (e.g. Van Aelst and Walgrave, 2002; Mattoni, 2008), women movements (Edwards, 2004; Pini, Brown and Previte, 2004), alternative media organizations such as Indymedia (Kidd, 2003), human rights activism (Lebert, 2003), the anti-war or peace movements (Shaw, 2005; Gillan, 2008), anti-corporate campaigns (Niesyto, 2007; Baringhorst, 2008) or hacktivism (Jordan, 2008).

Most generally, these protest actors are distinguished depending on the way they use ICTs and the internet. Vegh defines online activism as "a politically motivated movement relying on the internet" (2003: 71) and distinguishes these movements following their tactical use of the media: awareness-advocacy, organization-mobilization, and action-reaction. For Vegh (id.), strategies are either internetenhanced, i.e. the internet serves as an additional channel for protest, or internet-based, i.e. the internet constitutes a space for actions that are only possible online such as virtual sit-ins or hacking Web sites. The Net is either considered as an "additional tool" for mobilization and coordination of protest actions or a "new tactical site" (Lee, 2009: 16) in order to move collective action online. Van Laer and Van Aelst (2009) endorse a similar distinction in their recent study on the internet and action repertoires of social movements.

In their paper, 'Collective Action in the Age of the internet, Mass Communication and Online Mobilization', Postmen and Bursting (2002) propose two dimensions along which forms of collective action can be distinguished. First, the individualistic-collectivistic dimension differentiates actions that can be carried out by one person (such as letter writing, sabotage acts or forms of civil disobedience) from actions that require a large number of participants (such as labor disputes, demonstrations or mass petitioning). Second, they distinguish persuasive actions (e.g. such as letter writing, lobbying or petitioning) from actions that are more confrontational in nature (e.g.: demonstration, blockade, sabotage). Postmes and Brunsting argue that offline forms of collective action find their equivalent in the online realm. Indeed, letter writing has often been replaced by email writing, lobbying and petitioning have also been complemented by online equivalents, often supported by eparticipation initiatives such as the UK epetitioning system for example. The internet has also become a site of "virtual" struggle for direct action, forms of electronic civil disobedience, strikes or demonstrations in virtual worlds such as for example second life (Robinson, 2008).

However, online and offline worlds are increasingly interconnected and a dichotomized opposition between both domains is more and more criticized (e.g. Kneip and Niesyto, 2007). Similar binary oppositions characterize the research literature on collective action and ICTs. The private and the public are opposed, as well as local actions to national or global ones, etc. This paper argues that such dichotomies hinder the further maturation of the field. In order to confront the democratic - and often dichotomized - potential of the internet to current protest practices, we therefore propose to examine such claims in the light of the three axes distinguished by Vedel (2003, 2007) for studying the political uses of the internet.

\section{Three Axes of Political Internet Use}

The first axis proposed by Vedel focuses on information (section 2.1) and is based on the model of an "informed citizen", central to liberal democratic thought. Information is indeed sought to be a prerequisite for any political participation. The underlying model of citizenship is one of a "glass city" where governmental information is transparently available to interested citizens. The second axis is discussion and debate (section 2.2) relying on the model of an "active citizen" who shapes his political opinion by confronting his thoughts to those of other citizens or representatives in a public space or agora. This model can be linked to deliberative democratic systems. The 
third axis is the one of mobilization (section 2.3) considering that citizens need to participate more or less directly in the political decision-making. Such a "participative citizen" needs to be informed and engaged in a public sphere in order to actively contribute to the policy-process. This model can be linked to participative democratic thoughts. All three axes are based on an idealized model of democracy (liberal, deliberative or participative) and such assumptions tend to influence the current research on internet activism.

\subsection{Information}

Information is traditionally considered as a prerequisite for all forms of political participation, not only protest. In order to make up their minds, express their opinions (e.g. by voting) or contesting political practices, citizens need to be informed about what is happening in their country or region. It is commonly said that information used to be scarce at the beginning of the industrial age. At present, it is rather the abundance of information in our digital societies that challenges citizens and politicians alike.

The internet has been praised for providing access to huge amounts of information, raising hopes that this would lead to a betterinformed society and thus increased citizen participation (Rheingold, 1991). Free from state intervention or mainstream media intermediaries, citizens would thus be better informed about politics at lower costs and more efficiently (Bimber, 1998). Research indicates that the internet has become a primary source of information yet might not challenge mainstream media. "All models reveal that online media complement traditional media to foster political discussion and civic messaging. These two forms of political expression, in turn, influence civic participation" comment Shah et al. (2005: 531). However, the assumption that access to information leads to a better-informed citizenry has not been verified. Following a study conducted by Bimber (2001), it is not because people search for political information online that other forms of political activity are affected. Furthermore, he argues that citizens have limited capacities to absorb and process information. Increased access at lower costs does therefore not automatically increase participation levels.

Moreover, this assumption conceals an idealized version of the "informed citizens" that doesn't correspond to reality according to Vedel (2003). Chadwick equally argues: "it is unnecessary to assume that citizens are highly informed and highly motivated. Most citizens will fall into categories along a continuum, and it is highly unlikely that they will remain in one category in perpetuity. Most of us occupy positions between these two extremes, depending upon our contexts" (2009: 19). For Vedel (2003), such assumptions also recover the myth of political transparency that might never be achieved.

Next to the quantity of information available, the compression of time and space barriers has also been pointed out as increasing the diffusion of protest ideas, tactics, and strategies. Ayres points out "when a message is posted on a Web site, it is immediately accessible, crossing time and geographic boundaries without a concern for time zones, media coverage, or customs barriers" (1999: 138). Efficiency in the diffusion of activist information is indeed central to protest movements' strategies, especially when operating at a transnational level (e.g. Keck \& Sikkink, 1998). However, for Ayres, "while there is little question of the internet's ability to quickly disseminate information, there is a great deal of uncertainty about the value of this information. That is, much of the material available on the internet is often unreliable and clearly unverifiable." (1999: 141). For this author, the fast diffusion of contention could lead to increased riots and insecurity. However, such a scenario has neither been confirmed nor rejected by recent empirical research.

\section{Information: Key Concepts}

- Assumption: a «better informed citizen " is likely to participate in politics.

- Access does not equal participation. Quantity not quality.

- Time/space compression: rapid diffusion of information.

- The end of intermediaries? alternative media space. 
- Media literacy skills are new barriers for participation.

The media is an important channel for providing political information to citizens. Activists and scholars have always criticized the mass media system for favoring the positions of dominant political actors. The fast adoption of the internet by activist networks allows these to produce and publish alternative information. This development might challenge mass media outlets that are increasingly relying on user-generated input for their editorial content.

"The open and accessible character of the net means that traditional centers of power have less informational and ideational control over their environment than previously" argues Dahlgren (2009: 313). However, it does not make much sense to oppose the traditional mass media with alternative media sources as both spheres tend to influence each other. One clear strategy of activist networks is to impact on the information provided by the mass media (Breindl, 2009). Using micromedia (e.g. e-mails) and meso-media (activists' sites, blogs and webzines), activists' networks can indeed circumvent established news sources and produce their own independent information - Kavada (2009) speaks about the "websphere" of a movement or activist network. Nonetheless, traditional media and especially television remain important channels for mobilizing larger groups for protest actions (Castells, 2007).

Next to information diffusion, the internet offers also unlimited framing possibilities (Niesyto, 2007; Kavada, 2009). Framing and reframing particular struggles is a key strategy of protest movements. The concept of 'frames' proposed by Snow et al. (1986) can be defined as "organizing ideas (catchwords, images) that describe or represent a problem that, from the viewpoint of the scientific observer is not inherently given but a social construction" (Van De Donk et al., 2004: 12). Individuals, bloggers and activist groups enjoy unlimited editorial control for explaining, informing and developing their narratives online. Not surprisingly, a large part of the social movement literature is concerned with issues of framing that enables the construction of a collective identity, which is a central component for mobilizing people.
Additionally, the internet offers equal opportunities for monitoring governmental or corporate activities. Blogs for example play an increasing role in reversing Foucault's panopticon in which the state is watching the citizens. The internet raises hopes for enabling continuous citizen vigilance at a large scale (Chadwick, 2009). Following Hurwitz, the internet is a powerful tool for monitorial democracy, where "the citizen is called to action by volunteers who foresee some national or local crisis [...] and believe that some action must be taken in response" (Hurwitz, 1999: 660). But also in everyday life, activists groups use the internet in order to increase state transparency as for example by reorganizing governmental information such as MySociety with their site theyworkforyou.com in the UK that keeps track of elected officials.

In conclusion to this first axis, we agree with Chadwick when he argues that "the current era is characterized by the aggregation of huge amounts of information: those who can successfully mine, refine, and subsequently protect it are likely to emerge as dominant." (2009: 22). Even though technologies are often portrayed as equalizing forces, this is not necessarily what happens in practice. Significant usage and knowledge gaps persist. The "digital divide" remains a reality and should not be reduced to access issues as the concept recovers major usage differences. Thus the importance of favoring media literacy as part of civic competences in an ever more digital society (Dahlgren, 2009). As argues Lehtonen: "apart from being able to understand and interpret media texts, citizens are expected to adopt, filter and communicate masses of information coming from various sources" (2008: 173). Media skills are not only fundamental to citizens but to contemporary contentious movements at large (Garrett, 2006).

Issues of information overload and practices of disinformation need also to be addressed. Discussing this first axis shows indeed that the democratic potential of the internet regarding information recovers both an empowering - increased access and speed, control of the informational environment - but also a de-mobilizational aspect - media literacy and skills, fragmentation, information overload and practices of disinformation. The next 
section will highlight Vedel's second axis: discussion and debate.

\subsection{Discussion and Debate}

"Theories of democracy have treated the communicative interaction among citizens as vital. Talk among citizens is seen as basic to their political participation, to the functioning of the public sphere" (Dahlgren, 2009: xviii). The public sphere is certainly one of the most influential concepts in the academic literature on political participation and the internet. The public sphere constitutes a "network for communicating information and points of view" (Habermas, 1996: 360).

Early enthusiastic accounts considered the internet as an incarnation of the Habermasian public sphere based on rational discourse. Studies of discussion forums and chat room discussion however soon countered these assumptions by highlighting the fragmentation of such a public sphere. On the contrary, Keane (2000) describes a mosaic of microspheres (interpersonal communication), meso-spheres (local/national media) and macrospheres (international media), interconnected by the internet. Furthermore, these public spheres are not necessarily characterized by a general norm of rationality. Elite discourse may aim for rationality but many other forms of public communication and styles of communication would be excluded by uniquely taken rational discourse into account (Niesyto, 2007).

\section{Discussion: Key Concepts}

- Assumption: the "active citizen" shapes his opinion by rational debate.

- Public sphere: Plurality of dynamic and complex public spheres.

- Interactivity: homophily, passive forms of civic engagement.

- Glocal: local activities connected to global struggle.

A plurality of public spheres exists, "dynamic and spatially complex in nature" (Bentivegna, 2006: 336). Drawing upon Dahlgren (2005), Bentivegna usefully differentiates three dimensions of the public sphere: the structural, the representational and the inter- active dimension. The structural dimension comprises the mass media system and the social and political institutions that legislate on how the media operates. After a first phase of initial anarchism, private corporations have increasingly taken over cyberspace. For some time, political institutions have largely let the market control what was happening in cyberspace. However, recent legislative projects may indicate that increased governmental interventions regarding notably cybercrime or the fight against terror or child pornography can impact the structure of the internet.

The representational dimension comprises what is being published by the media, including micro and meso-media. As already mentioned above, the internet has disrupted mass media's dominance over information production. Anybody can now become his own producer of information. For Castells, the "development of interactive, horizontal networks of communication has induced the rise of a new form of communication, mass selfcommunication, over the internet and wireless communication networks" (2007: 239). Such conditions might be beneficial for protest movement and activist networks as new spaces of communication are opening up. However, the rapid proliferation of niche audiences comes along with fragmentation and specialization (Sunstein, 2001). Yet, such a fragmentation does not exclude the cooperation between various protest groups and is thus not necessarily counter-productive for progressive movements.

The dimension of interaction relates to one of the most saluted features of the internet: it's interactive potential. Contrary to other media, the internet allows one-to-one and many-tomany communications. However, "the degree of interactivity or real debate is often rather weak, as the forums and mailing lists are also used in order to inform or to mobilize" (Cammaerts and van Audenhove, 2005: 191). Discussion "tend(s) to be dominated by those already politically active in the offline world and functions within a homogeneous ideological framework" (ibid.). Homophily is one of the characteristics of many online communities in which people gather with like-minded individuals in order to debate issues they are interested in. Nonetheless e-mail lists enable rather passive or more active forms of civic 
engagement and are used by most protest movements for organizing actions but also for coordinating and internal decision-making.

Various scholars raised the idea that the internet favors the emergence of a transnational public sphere (e.g. Cammaerts and van Audenhove, 2005; Salter, 2003; Niesyto, 2007). The internet enables local activists to connect to global struggles and find support outside their countries of origin. Such discussions need to be linked to a tendency towards increased cosmopolitanism and transnationalism that shapes current forms of protest (e.g. Tarrow, 2006).

The discussion axis also unfolds a continuum of how the democratic potentialities of the internet have been put into practice. On the one side, fears of fragmentation are empirically grounded. Yet a renewal of the public sphere - or the public sphere(s) - has also been acknowledged by the literature and furthered debates about how to define these "new" spheres. The next section will review current literature concerning the mobilizational aspect of the internet.

\subsection{Mobilization}

In addition to discussions about the nature of internet-based public sphere(s), the concept of social capital is a highly discussed topic by the literature. The basic idea behind is that daily social contacts increase and support the development of horizontal civic trust and reciprocity (Putnam 1993). Various scholars therefore conclude that a functioning social network can be a prerequisite for political participation (Putnam 1993; Gillan, 2008; Vromen, 2008). While some authors deplore a weakening of social ties in current societies (Putnam, 2000), cyber-enthusiasts argue that computer-mediated communication supports social networks and new forms of community life (e.g. Rheingold, 1993).

One of the questions that have been addressed is whether online contacts can be considered as equal in the way they foster community bonds among individuals. In a comparative study between face-to-face (f2f) and computer-mediated-communication (CMC), Etzioni and Etzioni conclude: "far from finding that CMC systems cannot meet the needs of "real" communities, we find that there are no conceptual reasons or technical ones, that CMC-based communities, especially given additional technical development, could not become fully fledged communities" (1999: 247). Both systems seem to have strengths and weaknesses and are increasingly intertwined so that a separation between the online and the offline sphere cannot be upheld (Kneip and Niesyto, 2007).

Yzer and Southwell equally reject "the polar choices of isolation and interconnectedness" by arguing that "new communication technologies seem at best to have interacted with human group tendencies to produce yet again a world in which loneliness is common but not universal and social networks exist but have important limits" (2008: 12). For Kobayashi, Ikeda and Miyata, participation in online communities enhances social capital as online reciprocity "has a positive effect on intention to participate in online civic discussion" (2006: 582).

The literature on internet activism can be divided between the proponents of the mobilization hypothesis and the reinforcement theory (Stanley and Weare, 2004). Supporters of the former highlight the empowering potentialities of the internet as resource-poor actors benefit from it. Supporters of the latter consider that technology strengthens above all existing power structures.

Following Vromen, online mobilization often results in mobilizing the mobilized. In her study on how the Australian organization, GetUp, tries to mobilize citizens to participate in traditional politics, she concludes that there is a "reinforcement involvement of middleaged, highly educated, experienced participants" (2008: 123). On the other side, by lowering communication and coordination costs, ICT facilitate group formation, recruitment and retention while improving group efficiency, all of which contribute to increasing political participation (Garrett, 2006: 205, referring to Bonchek, 1995).

\section{Mobilization: Key Concepts}

- Assumption: the "participating citizen ». 
- Social capital : isolation vs. Interconnectedness.

- Online and offline worlds increasingly merge.

- The internet empowers resourcepoor actors yet new « digital » barriers to participation emerge.

- Active minorities overrepresented.

- Change of mobilising actors - difficulty to estimate who participates.

Considering that the internet facilitates political participation, Jensen (2006) notes nevertheless that online involvement remains determined by 'classical' factors such as resources, education, social capital and existing political participation. Additionally, new 'digital factors' such as access, competences and motivation to use ICTs constitute new hindrances to online political participation. The divide between those who have access to the network (but also the skills and desire to use it) and those who do not (or do not want to) constitutes another major challenge to esociety. Active minorities are often overrepresented in cyberspace (Corbineau \& Barchechath, 2003). Online political activities are rarely representative of the various groups constituting society. This is an important challenge to the principle of equality, central to all democracy models.

Finally, when discussing a change in mobilizational strategies, Chadwick points out the fast "repertoire switching" both between the online and the offline realm (spatial dimension) and between various campaigns (temporal dimension) (Chadwick, 2007; see also Vromen, 2008). Hybrid organizations mix various repertoires that are traditionally linked to the main political actors: political parties, interest groups, and social movements. This increased flexibility contributes to the success of some internet-based movements but as Dahlgren notes: "given the fluid character of many of these net-based movements, and the ease of joining and withdrawing, it is really difficult to estimate what portion of the citizenry is actually involved" (2004: xviii).

\section{Discussion and Concluding Remarks}

This paper has discussed the democratic potentialities of the internet in the light of recent, empirical and theoretical literature. After having conceptualized internet activism, we have introduced Vedel's three axes: information, discussion and mobilization. They structure the discussion on the democratic potentialities of the internet.

The axis of information discussed potentialities such as access, diffusion and production of information by protest movements. ICTs have contributed to disrupting elite dominance in the sphere of information production and control. If easier access to information can be empowering for some actors, it may also have its pitfalls as increased information abundance augments the need for media literacy skills. Actors who can best manage a fragmented informational environment will likely emerge as political counter-forces.

The axis of discussion examined the concept of the public sphere by considering the impact of ICTs on three of its dimensions: structure, representation and interaction. All of these dimensions seem to be affected by recent technological developments and wider mechanisms such as globalization. Many scholars raised concern about the fragmentation of the public sphere that therefore can hardly fulfill the criteria of a Habermasian conceptualization. However, such a fragmentation does not necessarily hinder cooperation among very different civil society organizations. Further research will need to address this point.

The axis of mobilization reviewed the discussion on social capital and mobilizational strategies. It is argued that computermediated-communication is complementary to face-to-face interactions. The dichotomy between both realms needs to be deconstructed in a world where the internet constitutes a bridge between the online and the offline, the local and the global, the private and the public. We argue for a need to overcome dichotomies and binary oppositions associated with the democratic potentialities of the internet. Many scholars note that there is a weakening of boundaries; Bimber et al. (2005) and Flanagin et al. (2006) for example argue for 
the need to reconceptualize collective action as the public-private boundary tends to decrease: "just as the spread of industrialization tended to create and strengthen private-public boundaries, the spread of digital technologies is now weakening them. The result is changing manifestations of collective action, as certain boundaries became less and then more easily crossed" (Bimber et al., 2005: 384).

We need to analyze critically the too often polarized oppositions - such as social isolation or global interconnectedness, informed versus apathetic citizens - that are used by internet scholars. We need to make more explicit normative assumptions that underpin both practice and interpretation. Explore what is beyond idealized versions of citizenship (the informed, the active, the participative citizen) enables us to make sense of fluid forms of involvement, shifting dependent on the con- text and the issue. In order to make these more explicit, we need to further conceptualize internet activism. What kind of politics do we talk about? What kind of technology? How do social agents socially construct the technological infrastructure they are using? The variety of perspectives enriches the study of internet activism yet clearly defining the concepts used would facilitate conversations across the field.

Finally, we also need to look at other forms of protest than progressive movements and 'success stories'. If the internet can be used for furthering democracy, radical groups can equally use it to pursue their agenda. In fact, studying internet activism offers just another entry point - from the technological perspective - into understanding current phenomena of political struggle and activism for social change.

\section{References}

Ayres, J. M. (1999). From the streets to the internet: The cyber-diffusion of contention. Annals of the American Academy of Political and Social Science, (566):132-143.

Barlow, J. P. (1996). An Declaration of Independence of Cyberspace, Retrieved from: http://homes.eff.org/ barlow/Declaration-Final.html (last accessed 4/11/2009).

Baringhorst, S. (2008). The political empowerment of citizen consumers - opportunities and problems of anti-corporate campaigning on the net, In Häyhtiö, T., Rinne, J. (eds.), Net Working/ Networking: Citizen Initiated internet Politics, (pp. 281-309), Tampere: Tampere University Press.

Beck, U. (1997). The Reinvention of Politics. Cambridge: Polity Press.

Bennett, W.L. (2004). Communicating global activism: strengths and vulnerabilities of networked politics, In Van De Donk, W., Loader, B.D., Nixon, P.G. and Rucht, D. (Ed.) (2004). Cyberprotest: New media, citizens and social movements. (pp. 123-146). London: Routledge.

Bentivegna, S. (2006). Rethinking Politics in the Worlds of ICT, European Journal of Communication, 21(3):331-343

Berry, D. M. (2008). Copy, Rip, Burn: The Politics of Copyleft and Open Source. London: Pluto Press.

Bimber, B. (1998). The internet and Political Transformation: Populism, Community, and Accelerated Pluralism. Polity, 31(1):133-46

Bimber, B. (2001). Information and Political Engagement in America: The Search for Effects of Information Technology at the Individual Level, Political Research Quarterly, 54(1): 53-67

Bimber, B., Flanagin, A. J. \& Stohl, C. (2005). Reconceptualizing collective action in the contemporary media environment. Communication Theory, 15:389-413.

Bonchek, M., 1995. Grassroots in Cyberspace: Using Computer Networks to Facilitate Political Participation, MIT Artificial Intelligence Laboratory Working Paper 95-2.2, Presented at the 53rd Annual Meeting of the Midwest Political Science Association, Chicago, USA.

Breindl, Y., (2009). Internet-based Protest in European Policy- Making: the Case of Digital Activism, International Journal of E-politics, 1(1):57-72

Bucchi, M., Neresini, F. (2008). Science and Public Participation, In Hackett, E.J., Amsterdamska, O., Lynch, M., Wajcman, J. (eds.), The Handbook of Science and Technology Studies, (pp. 449-472), $3^{\text {rd }}$ edition, Cambridge: MIT Press.

Burstein, P. (1998). Interest Organizations, Political Parties, and the Study of Democratic Politics. In Costain, A. N. \& McFarland, A. S., (eds.) Social Movements and American Political Institutions, (pp. 39-56), Lanham, Maryland: Rowman \& Littlefield Publishers.

Cammaerts, B. \& Van Audenhove, L. (2005), Online Political Debate, Unbounded Citizenship and the Problematic Nature of a Transnational Public Sphere, Political Communication, 22(2): 179-96 
Cammaerts, B. (2007) 'Media and communication strategies of glocalised activists: beyond media-centric thinking', in B. Cammaerts and N. Carpentier (Eds.) Reclaiming the Media: communication rights and expanding democratic media roles, Bristol: Intellect, pp. 265-88.

Castells, M. (2001). The Internet Galaxy. Oxford: Oxford University Press.

Castells, M. (2007). Communication, Power and Counter-power in the Network Society, International Journal of Communication (1):238-266

Chadwick, A. (2006). Internet Politics: States, citizens, and new communication technologies. New York, NY: Oxford University Press.

Chadwick, A. (2007). Digital network repertoires and organizational hybridity. Political Communication, (24):283-301.

Chadwick, A. (2009). Web 2.0: New Challenges for the Study of E-Democracy in an Era of Informational Exuberance. J/S: Journal of Law and Policy For the Information Society, 5(1):1-32.

Corbineau, B., Barchechath, E. (2003). The Discourse on eDemocracy: Where are We Heading? In Building the Knowledge Economy: Issues, Applications; Case Studies, IOS Press, Oxford, UK.

Dahlgren, P. (2004) 'Foreword', In W. Van Donk, B.D. Loader, P.G. Nixon and D. Rucht (eds.) Cyberprotest: New Media, Citizens and Social Movements (pp. xi-xvi) London and New York: Routledge.

Dahlgren, P. (2005) 'The internet, Public Spheres, and Political Communication: Dispersion and Deliberation', Political Communication, 22(2): 147-62.

Dahlgren, P. (2009). Media and Political Engagement: Citizens, Communication and Democracy, 1st ed., New York: Cambridge University Press.

Dreyfus, H. (2001). On the Internet (Thinking in Action), London: Routledge.

Dutton, W. (1996). Network Rules of Order: Regulating Speech in Public Electronic Fora. Media, Culture and Society, (18):269-90.

Earl, J., Schussman, A. (2003). The new site of activism: Online organizations, movement entrepreneurs, and the changing location of social movement decision-making. Consensus Decision Making: Northern Ireland and Indigenous Movements, (24):155-187.

Edwards, A. (2004). The Dutch women's movement online: internet and the organizational infrastructure of a social movement, In Van De Donk, W., Loader, B.D., Nixon, P.G \& Rucht, D. (Eds.) Cyberprotest: New Media, Citizens, and Social Movements, (pp. 183-206) London: Routledge.

Etzioni, A. \& Etzioni, O. (1999). Face-to-Face and Computer-Mediated Communities, A Comparative Analysis. The Information Society, (15): 241-248.

Flanagin, A. J., Stohl, C. \& Bimber, B. (2006). Modeling the Structure of Collective Action. Communication Monographs, 73(1): 29-54.

Flichy, P. (2001). L'imaginaire d'Internet, Paris: La Découverte.

Garrett, R. K. (2006). Protest in an information society: A review of literature on social movements and new ICTs. Information, Communication \& Society, 9(2): 202-224.

Garrido, M., Halavais, A., (2003). Mapping Networks of Support for the Zapatista Movement: Applying Social-Network Analysis to Study Contemporary Social Movements, In McCaughey, M. \& Ayers, M. D. (Eds.) Cyber-activism: Online Activism in Theory and Practice, (pp. 165-184) New York: Routledge.

Giddens, A. (1991). The Consequence of Modernity. Cambridge: Polity Press.

Gillan, K. (2008). Diverging attitudes to technology and innovation in Anti-War movement organisations, In Häyhtiö, T., Rinne, J. (eds.), Net Work-ing/ Networking: Citizen Initiated internet Politics, (pp. 74-102). Tampere: Tampere University Press.

Habermas, J. (1996). Between Facts and Norms. London: Polity Press

Hardt, M., Negri, A. (2000). Empire, Cambridge: Harvard University Press.

Häyhtiö, T., Rinne, J. (2008). Introduction: Seeking the citizenry on the internet - Emerging virtual creativity, In Häyhtiö, T., Rinne, J. (eds.), Net Working/ Networking: Citizen Initiated internet Politics, Tampere: Tampere University Press.

Hess, D. J., Breyman, S., Campbell, N., Martin, B., (2008), Science, Technology, and Social Movements, In Hackett, E.J., Amsterdamska, O., Lynch, M., Wajcman, J. (eds.), The Handbook of Science and Technology Studies, (pp. 473-498), $3^{\text {rd }}$ edition, Cambridge: MIT Press.

Hill, K.A., Hughes, J.E. (1998). Cyberpolitics: Citizen Activism in the Age of the Internet, Rowman and Littlefield, New York.

Hurwitz, R. (1999). Who Needs Politics? Who Needs People? The Ironies of Democracy in Cyberspace. Contemporary Sociology, 28(6): 655-661

Jensen, J. L., (2006). The Minnesota E-Democracy Project; Mobilizing the Mobilized? In Internet and Politics, (pp. 39-58) Routledge, Oxon, UK,

Jordan, T. (2008). Hacking: Digital Media and Technological Determinism. Cambridge, Polity Press.

Jordan, T., Taylor, P. A. (2004). Hacktivism and cyberwars: Rebels with a cause? London and New York: Routledge.

Kahn, R., Kellner, D. (2004). New media and internet activism: From the battle of Seattle to blogging. New Media and Society, (6):87-95. 
Kavada, A. (2005). "Exploring the role of the internet in the 'Movement for alternative globalization': The Case of the Paris 2003 European Social Forum". Westminster Papers in Communication and Culture, London: University of Westminster Press, 2(1), 2-95

Kavada, A. (2008). Decentralization and Communication: Email lists and the organizing process of the European Social Forum. In Karatzogianni, A. (Ed.), Cyber Conflict and Global Politics, (pp. 205-221) London: Routledge.

Kavada, A. (2009). Collective Action and the 'Participatory Web': A Comparative Analysis of Avaaz.org and Openesf.net, Paper presented at the Conference "Shaping Europe in a Globalized World? Protest Movement and the Rise of a Transnational Civil Society”, Zurich, June 23-26, 2009.

Keane, J., (2000). Structural Transformations of the Public Sphere. Hacker, K.L., van Dijk, J. (eds.). Digital Democracy: issues of theory and practice, (pp. 70-90). Thousand Oaks, CA: Sage Publications.

Keck, M.E., Sikkink, K. (1998). Activists beyond borders: Advocacy networks in international politics. Ithaca, NY: Cornell University Press

Kidd, D. (2003). Indymedia.org: A New Communications Commons, In McCaughey, M. \& Ayers, M. D. (Eds.) (2003) Cyberactivism: Online Activism in Theory and Practice, New York: Routledge, pp. 47-70

Kirkpatrick, G. (2004), Critical Technology: A Social Theory of Personal Computing, Aldershot: Ashgate.

Kneip, V., Niesyto, J. (2007) Interconnectivity in the 'public of publics' - the example of Anti-Corporate Campaigns. Paper presented at Changing politics through digital networks: The role of ICTs in the formation of new social and political actors and actions, University of Florence.

Kobayashi, T., Ikeda, K. i., \& Miyata, K. (2006). Social capital online: Collective use of the internet and reciprocity as lubricants of democracy. Information, Communication \& Society, (9):582-611.

Lebert, J. (2003). Wiring Human Rights Activism: Amnesty International and the Challenges of Information and Communication Technologies, In McCaughey, M. \& Ayers, M. D. (Eds.) (2003) Cyberactivism: Online Activism in Theory and Practice, (pp. 209-232), New York: Routledge.

Lee, J. (2009). Considering a New Keyword: internet Activism, Paper presented at the ICA Conference, "Keywords in Communication", May 21-25, 2009, Chicago, USA.

Lehtonen, P. (2008). Civic expression on the Net: Different faces of public engagement?, In Häyhtiö, T., Rinne, J. (eds.), Net Working/ Networking: Citizen Initiated internet Politics, (pp. 163-188), Tampere : Tampere University Press.

Levy, S. (1984). Hackers: Heroes of the Computer Revolution, Penguin: London.

Lévy, P. (2002). Cyberdémocratie: essai de philosophie politique, Paris: Ed. Odile Jacob.

Lilleker, D.G. \& Jackson, N. (2008). Politicians and Web 2.0: the current bandwagon or changing the mindset? Paper presented at Politics: Web 2.0: An International Conference, Royal Hollloway, UK.

Margolis, M., Resnick, D., (2000). Politics as Usual: The Cyberspace "Revolution", London: Sage.

Massit-Folléa, F., (1997). La démocratie électronique : mise en perspectives, Information et démocratie: mutation du débat public, (pp. 105-130). Fonetnay/Saint Cloud: ENS Ed.

Mattoni, A., (2008). ICTs in National and Transnational Mobilizations, triple C, 6(2):105-124

McAdam, D., McCarthy, J.D. and Zald, M.N. (1996) Comparative perspectives on social movements: political opportunities, mobilizing structures, and cultural framings, New York: Cambridge University Press.

McAdam, D., Tarrow, S., Tilly, C. (2001). Dynamics of Contention, New York: Cambridge University Press.

Morris, D., Delafon, G. (2002). Vote.com ou comment internet va révolutionner la politique, Mesnil-sur- l'Estrée: Ed. Plon.

Morrison, A. H. (2009). An Impossible Future: John Perry Barlow's 'Declaration of the Independence of Cyberspace', New Media Society, 11(1\&2):53-72

Neumayer, C., Raffl, C. (2008). Facebook for Protest? The Value of Social Software for Political Activism in the Anti-FARC Rallies, DigiActive Research Series.

Niesyto, J. (2007). Comparative Study of Transnational Anti-Corporate Campaigns - Research Design and Preliminary Results. In LMU Munich, Germany.

Pini, B., Brown, K., Previte, J. (2004). Politics and identity in cyberspace: a case study of Australian Women in Agriculture online, In Van De Donk, W., Loader, B.D., Nixon, P.G \& Rucht, D. (eds.) Cyberprotest: New Media, Citizens, and Social Movements, (pp. 259-275), London: Routledge.

Polat, R. K. (2005). The internet and Political Participation: Exploring the Explanatory Links, European Journal of Communication, 20(4):435- 459

Postmes, T., Brunsting, S. (Fall 2002). Collective Action in the Age of the internet: Mass Communication and Online Mobilization, Social Science Computer Review, 20(3)

Powell, A., (2008). Co-productions of Technology, Culture and Policy in the North American Community Wireless Networking Movement. PhD Thesis, Concordia University, Montréal. Retrieved March, 30, 2009, from: http://www.alisonpowell.ca/?page_id=71

Putnam, R. D. (1993). Making democracy work. Civic traditions in Modern Italy, Princeton: Princeton University Press.

Putnam, R. D. (2000) Bowling Alone: The Col lapse and Revival of American Community, New York: Simon and Schuster.

Riemens P. (2002). Quelques réflexions sur la "culture hacker", Multitudes, 1(8): 181-187 
Rheingold, H. (1991) 'The Great Equalizer', Whole Earth Review 71 (Summer): p. 6.

Rheingold, H. (1993). The Virtual Community: homesteading the electronic frontier, MA: Addison-Wesley.

Robinson, B. (2008), Picket Lines in a Virtual World: Labour and the Production of (Cyber)Space, Paper presented at the IADIS International Conference, 9-12 April 2008, Algarve, Portugal.

Ronfeld, D., Arquilla, J. (2001). Emergence and Influence of the Zapatista Social Netwar, In Ronfeld, D., Arquilla, J., Networks and Netwars: The Future of Terror, Crime and Militancy, (pp. 171-199) Santa Monica: Rand.

Rucht, D. (1994). Modernisierung und neue soziale Bewegungen. Deutschland, Frankreich und USA im Vergleich, Frankfurt/New York: Campus.

Rucht, D. (2005), Cyberprotest - Möglichkeiten und Grenzen netzgestützter Proteste, Tagung "Von neuen Öffentlichkeiten zur heimlichen Medienrevolution - Welche Chancen hat eine kritische internetkultur?" Wiesbaden, May 7-8, 2005

Salter, L. (2003). Democracy, new social movement, and the internet: A Habermasian analysis. In M. McCaughey \& M. D. Ayers (eds.), Cyberactivism: Online activism in theory and practice. (pp. 117-144), New York, NY: Routledge.

Scott, A. and Street, J. (2000). From media politics to e-protest, Information, Communication and Society, 3 (2): 215-40.

Shah, D.V., Cho, J., Eveland, W. P. Jr., Kwak, N. (2005). Information and Expression in a Digital Age: Modeling internet Effects on Civic Participation, Communication Research, 32(5): 531-565.

Shaw, M. (2005). Peace Activism and Western Wars: Social Movements in mass-mediated global politics, In de Jong, W., Shaw, M., Stammers, N., Global Activism, Global Media, (pp. 133-145), London, Pluto Press.

Snow, D., Rochford, A., Burke, E., Worden, S.K \& Benford, R. D. (1986). Frame Alignment Processes, Micromobilization and Movements Participation. American Sociolgical Review, 51(4):464-481.

Stanley, J. W., Weare, C. (2004). The Effects of Internet Use on Political Participation: Evidence From an Agency Online Discussion Forum. Administration \& Society, 36(5):503-527

Sunstein, C. (2001). Republic.Com. Princeton, NJ: Princeton University Press.

Tarrow, S. (2006). The New Transnational Activism, Cambridge: Cambridge University Press.

Valenzuela, S., Park, N., Kee, K. F. (2009), Is There Social Capital in a Social Network Site?: Facebook Use and College Students' Life Satisfaction, Trust, and Participation, Journal of Computer-Mediated Communication, (14):875-901

Van Aelst, P. \& Walgrave, S. (2002) 'New media, new movements -The role of the internet in shaping the 'anti-globalisation movement', Information, Communication \& Society, 5(4): 465- 493.

Van De Donk, W. B. H. J., Snellen, I. Th. M., Tops, P. W. (eds) (1995). Orwell in Athens. A Perspective on Informatization and Democracy. Amsterdam: IOS Press.

Van De Donk, W., Loader, B.D., Nixon, P.G \& Rucht, D. (eds.) (2004) Cyberprotest: New Media, Citizens, and Social Movements, London: Routledge.

Van Laer, J., Van Aelst, P. (2009) 'Cyber-Protest and Civil Society: the Internet and Action Repertoires of Social Movements', In Jewkes, Y., Yar, M., (eds.), Handbook on Internet Crime. (pp. 230-254), Portland: Willan Publishing.

Vanobberghen, W. (2007), 'The marvel of our time': visions surrounding the introduction of radio broadcasting in Belgium 1923-1928, Paper presented at Media history and history in the media: Media and time, Wales, Gregynog (University of Aberyswyth), 28 - 30 March 2007.

Vedel, T. (2003). L'idée de démocratie électronique: origines, visions, questions. Le désenchantement démocratique, (pp. 243-266), La Tour d'Aigues: Editions de l'aube.

Vedel, T. (2007). Les usages politiques d'internet, La démocratie électronique, (pp. 15-26), Paris: Ed. La Documentation française.

Vegh, S. (2003). Classifying forms of online activism: The case of cyberprotests against the World Bank. In M. McCaughy \& M. D. Ayers (Eds.), Cyberactivism: Online activism in theory and practice. (pp. 71-96) New York: Routledge.

Vromen, A. (2008). Political change and the internet in Australia: introducing GetUp, In Häyhtiö, T., Rinne, J. (eds.), Net Working/ Networking: Citizen Initiated internet Politics, (pp. 103-126), Tampere: Tampere University Press.

Yzer, M. C., Southwell, B.G., (2008). New Communication Technologies, Old Questions, American Behavioral Scientist, $(52): 8-20$

\section{About the Author}

\section{Yana Breindl}

Yana Breindl is a doctoral student at the Department of Information and Communication Sciences at Universite Libre de Bruxelles (ULB) in Belgium. She holds a BA and Master's degree in Information and Communication Sciences with a specialization in Journalism from ULB (2007). Her academic work deals with digital activism that aims to influence European decision-making. She is particularly interested in the articulation between traditional politics and so-called "life-politics" and the link between online and offline realms. (ybreindl@ulb.ac.be). 